\title{
KELAYAKAN PENGGUNAAN PROBIOTIK RICA KEMASAN SERBUK UNTUK PEMELIHARAAN PASCA LARVA UDANG WINDU Penaeus monodon DALAM BAK TERKONTROL
}

\author{
Bunga Rante Tampangallo\#, Ike Trismawanti, dan Muliani \\ Balai Riset Perikanan Budidaya Air Payau dan Penyuluhan Perikanan \\ Jl. Makmur Dg. Sitakka No. 129, Maros, Sulawesi Selatan 90512
}

(Naskah diterima: 9 Januari 2018; Revisi final: 5 September 2018; Disetujui publikasi: 5 September 2018)

\begin{abstract}
ABSTRAK
Probiotik RICA kemasan cair telah diaplikasikan pada pemeliharaan udang windu P. monodon maupun vaname Litopenaeus vannamei. Namun, probiotik kemasan cair dirasa banyak mengalami kendala dalam hal pengiriman. Alternatif bentuk kemasan yang saat ini sedang dikaji adalah bentuk kemasan serbuk. Penelitian ini bertujuan mengetahui viabilitas probiotik RICA setelah dikemas dalam bentuk serbuk, waktu penyimpanan, serta pengaruhnya terhadap sintasan dan pertumbuhan benih udang windu yang dipelihara dalam bak terkontrol. Penelitian dilakukan dalam dua tahap, yakni penepungan probiotik, pengamatan populasi probiotik, dan aplikasinya pada pemeliharaan udang windu. Wadah pemeliharaan udang windu menggunakan bak fiber volume 500 liter. Udang uji yang digunakan adalah udang windu PL-12 dengan kepadatan 200 ekor per bak. Penelitian menggunakan rancangan acak lengkap empat perlakuan tiga ulangan. Perlakuan menggunakan probiotik serbuk RICA-4 (A), (B) probiotik RICA-5, (C), probiotik RICA-1, dan (D) tanpa probiotik. Hasil penelitian menunjukkan bahwa populasi probiotik RICA setelah diserbukkan berkisar $10^{7} \mathrm{sel} / \mathrm{mL}$. Sintasan, bobot, dan panjang udang windu setelah dipelihara selama 48 hari dengan menggunakan probiotik RICA serbuk belum memberikan hasil yang signifikan ( $P>0,05)$, namun pemberian probiotik RICA telah meningkatkan total hemolim udang windu secara signifikan $(P<0,05)$ dibanding kontrol. Pada aplikasi probiotik ini terjadi pertumbuhan lumut dalam bak pemeliharaan akibat penggunaan tepung kanji sebagai filler.
\end{abstract}

KATA KUNCl: probiotik; udang windu; sintasan; pertumbuhan; hemolim

ABSTRACT: The application viability of RICA's probiotic powder in tiger shrimp (Penaeus monodon) post-larvae culture reared in controlled tanks. By: Bunga Rante Tampangallo, Ike Trismawanti, and Muliani

RICA probiotics have been tested in multiple farms of black tiger shrimp P. monodon and whiteleg shrimp Litopenaeus vannamei with some promising results. However, the probiotics' distribution in theform of liquid faces some limitations due to transportation regulations involving liquid-based substances. A powder form might be an easy and secure alternatively for the distribution of the probiotics via airplane. The purpose of the study was to observe the viability of RICA probiotics after powdering and storage as well as their influences on the survival and growth rates of black tiger shrimp reared in controlled tanks. The study was conducted in three stages which were the pow dering of the probiotic, observation of the probiotics' bacteria population, and its application in shrimp rearing. The research was designed in a completely randomized design where 200 shrimps aged PL-12 reared in each tank and applied with three different powder probiotics namely (A) RICA-4, (B) RICA-5, and (C) RICA-1 as the treatments, and (D) without adding probiotic as a control. The result showed that the probiotic population after powdering ranged around $10^{7} \mathrm{cell} / \mathrm{s} / \mathrm{mL}$. Thesurvival rate, body length, and weight of shrimps after 48 days of rearing showed insignificant results $(P>0.05)$ among the treatment. However, RICA-1 had an increase in the total of hemocytes of the shrimps $(P<0.05)$ compared to control. The emergence of moss in the containers became a constraint during the experiment.

KEYWORDS: probiotics; black tiger shrimp; survival; growth; hemocytes

\# Korespondensi: Balai Riset Perikanan Budidaya Air Payau dan Penyuluhan Perikanan. Jl. Makmur Dg. Sitakka No. 129, Maros, Sulawesi Selatan 90512, Indonesia.

Tel.: + 62411371544

E-mail: bungatampangallo@ yahoo.com 


\section{PENDAHULUAN}

Brevibacillus laterosporus (BT951) telah diisolasi oleh Muliani et al. (2006) dari tambak udang windu (P. monodon) dan telah dijadikan sebagai isolat probiotik RICA-1, demikian halnya isolat probiotik RICA-4 dan RICA-5 yang diisolasi oleh Tampangallo \& Nurhidayah (2010) dari makroalga dan teridentifikasi sebagai Bacillus subtilis (BM12) dan Bacillus licheniformis (BM 58). B. laterosporus BT951 adalah bakteri gram positif, berbentuk batang, katalase, dan oksidase positif, indol negatif, dan bersifat motil (Muliani et al., 2011). Selanjutnya dilaporkan sifat menguntungkan dari isolat ini adalah tidak bersifat patogen terhadap larva udang windu dan mampu menghambat pertumbuhan $\mathrm{V}$. harveyi.

Penggunaan kombinasi isolat probiotik RICA yang diisolasi dari laut pada pemeliharaan benur di bak terkontrol dapat meningkatkan sintasan benur secara signifikan dibanding kontrol tanpa probiotik (Atmomarsono et al., 2009). Beberapa spesies bacillus telah dimanfaatkan sebagai probiotik pada budidaya udang terintegrasi (Haseeb, 2011), budidaya udang vaname (Zokaei et al., 2009) dan dicampur dengan pakan udang (Widanarni et al., 2014).

Isolat-isolat probiotik RICA juga telah diaplikasikan pada budidaya udang windu maupun vaname di tambak dan terbukti dapat meningkatkan sintasan dan produksi udang (Tahe et al., 2015; Sulestiani et al., 2016). Probiotik RICA kemasan cair dirasa kurang praktis dalam hal pengiriman, terutama ke pulau lain melalui transportasi udara. Probiotik kemasan cair membutuhkan perlakuan khusus dalam pengiriman sehingga menyebabkan biaya transportasi lebih mahal dibandingkan dengan produk dalam bentuk non-cair. Produk kemasan dari probiotik juga bertujuan untuk meningkatkan efektivitas probiotik dan mempermudah aplikasi di lapangan. Hasil penelitian menunjukkan bahwa untuk mengurai bahan organik pada titik tertentu di dasar petakan tambak, maka dapat dipilih probiotik dalam bentuk tablet agar tetap berada pada titik/dasar tambak yang hendak diperbaiki/ treatment, sedangkan apabila sasarannya adalah media air budidaya maka yang efisien adalah kemasan serbuk atau cair karena mudah tersebar atau larut dalam air (Newman, 2011).

Probiotik RICA ini pun telah diuji co ba untuk dibuat dalam bentuk serbuk dengan menambahkan tepung kanji. Aktivitas menguntungkan dari isolat probiotik RICA yang telah diserbukkan diharapkan masih tetap aktif seperti halnya dengan probiotik cair. Tujuan penelitian ini adalah untuk mengetahui viabilitas probiotik RICA setelah dikemas dalam bentuk serbuk dan waktu penyimpanan serta pengaruhnya terhadap sintasan dan pertumbuhan benih udang windu yang dipelihara dalam bak terkontrol.

\section{BAHAN DAN METODE}

\section{Persiapan Serbuk Probiotik RICA}

Persiapan pembuatan serbuk probiotik RICA meliputi sterilisasi tepung kanji (400 g) yang akan digunakan sebagai filler/pengisi probiotik RICA cair dengan menggunakan autoclove pada suhu $121^{\circ} \mathrm{C}$, tekanan 1 atm selama 15 menit; peremajaan dan perbanyakan isolat probiotik RICA-1, 4, dan 5; pengamatan kepadatan probiotik sebelum dan sesudah dalam kemasan serbuk.

Probiotik RICA-1, 4, dan 5 masing-masing dikultur di media nutrien broth (Difco) sebanyak $200 \mathrm{~mL}(1,6$ g nutrien broth ditambahkan $\mathrm{NaCl} 3 \mathrm{~g}$ dan dilarutkan dalam aquades $200 \mathrm{~mL}$ ). Probiotik ini diinkubasi di atas inkubator bergoyang selama 24 jam. Kepadatan probiotik cair pada kondisi awal kemudian di-sampling dengan menggunakan metode split/sebar pada media Triptic soya agar (TSA) plate (4 g TSA ditambah 1,5 g $\mathrm{NaCl}$ dan dilarutkan dalam $100 \mathrm{~mL}$ akuades). Probiotik RICA cair ini dipindahkan ke dalam wadah gelas piala steril.

Tepung kanji steril $(400 \mathrm{~g})$ dimasukkan sedikit demi sedikit ke dalam probiotik cair tadi. Setelah adonan probiotik menjadi kalis, adonan ini kemudian disimpan dalam inkubator $40^{\circ} \mathrm{C}$ steril selama 1-2 jam. Tepung yang masih tersisa kemudian dimasukkan semua ke dalam adonan probiotik tadi lalu diaduk lagi agar merata lalu dibagi ke dalam nampan steril kemudian dikeringkan dalam oven pada suhu $40^{\circ} \mathrm{C}$ selama 24-48 jam. Campuran tepung kanji dan probiotik RICA yang telah kering kemudian di-sampling kepadatannya dengan menggunakan metode sebar pada media TSA plate. Setelah diinkubasi selama 48 jam populasi bakteri yang tumbuh pada media TSA plate dihitung secara manual.

Probiotik serbuk ini kemudian disimpan dalam wadah stoples pada suhu ruang. Sampling kepadatan bakteri probiotik serbuk setelah penyimpanan (selama 10 bulan) dilakukan setiap bulan dengan cara mengambil $1 \mathrm{~g}$ probiotik dalam kemasan serbuk, diencerkan kemudian disebar pada media TSA plate.

\section{Persiapan Wadah, Media Pemeliharaan, dan Hewan Uji}

Wadah yang digunakan pada penelitian ini adalah bak fiber berbentuk persegi empat berukuran $50 \mathrm{~cm}$ x $50 \mathrm{~cm}$ x $50 \mathrm{~cm}$ sebanyak 12 buah. Bak tersebut dipasangi selang dan batu aerasi sebanyak empat titik per bak, lalu diisi dengan air laut salinitas 30 ppt yang 


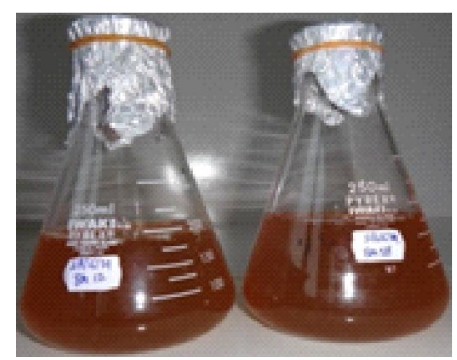

A

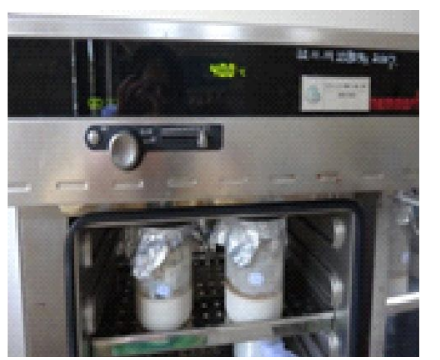

B

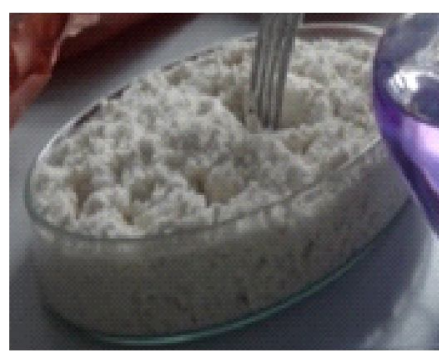

C

Gambar 1. Proses pembuatan probiotik RICA serbuk; probiotik RICA cair (a), probiotik yang telah ditambahkan tepung kanji dan diinkubasi dalam oven (b), dan contoh probiotik RICA setelah diserbukkan (c).

Figure 1. Processes of powdering RICA probiotics; liquid form of probiotics RICA (a), probiotics after addition with starch and incubation in oven (b), and powder form of probiotics RICA (c).

telah melalui membran filter $0,2 \mu \mathrm{m}$ hingga ketinggian $45 \mathrm{~cm}$.

Hewan uji yang digunakan pada penelitian ini adalah benur udang windu PL-12 yang diperoleh dari Instalasi Perbenihan Udang Windu (IPUW), Balai Penelitian dan Pengembangan Budidaya Air Payau di Kabupaten Barru, Sulawesi Selatan. Bobot rata-rata benur PL-12 yang digunakan adalah 0,002 g/ekor.

\section{Pemeliharaan Benur Udang}

Benur PL-12 ditebar sebanyak 200 ekor per bak. Sebelum benur ditebar, semua bak pemeliharaan ditambahkan dengan plankton Cheotoceros amami. Plankton ini dapat berfungsi sebagai pakan alami untuk benur sekaligus sebagai peneduh bagi benur agar lebih mudah beradaptasi dengan lingkungannya yang baru. Benur diberi pakan sebanyak 3\% dari bobot benur dengan frekuensi pemberian tiga kali sehari, yaitu pukul 07.00, 12.00 dan 17.00. Penggantian air sebanyak 30\%dilakukan seminggu sekali dan probiotik diberikan setiap hari sesuai dengan perlakuan masingmasing sebanyak 0,5 g. Pemeliharaan udang dilakukan selama 48 hari.

\section{Rancangan Penelitian}

Penelitian dilakukan menggunakan Rancangan Acak Lengkap (RAL) dengan empat perlakuan dan tiga ulangan, yakni: $A=$ pemberian probiotik serbuk RICA$4, B=$ pemberian probiotik serbuk $\mathrm{RICA}-5, \mathrm{C}=$ pemberian probiotik serbuk RICA-1, dan $D=$ tanpa pemberian probiotik (kontrol).

Bobot benur diukur sebelum ditebar, setelah tiga minggu pemeliharaan dan di akhir penelitian. Sintasan dan total sel hemosit udang yang dipelihara dihitung pada saat panen. Total sel hemosit diamati dengan mengambil sampel benur sebanyak satu ekor per bak dimasukkan dalam mikrotube yang telah berisi 0,3 $\mathrm{mL}$ antikoagulan (trisodium sitrat $3,8 \%$ lalu digerus kasar. Cairan gerusan ini kemudian diambil dengan menggunakan pipet tetes lalu diteteskan di atas hemositometer. Sel hemosit dihitung di bawah mikroskop dengan pembesaran $4.000 x$ menggunakan bilik 25 . Total sel hemosit dihitung menggunakan rumus:

$$
N=\left(\frac{n 1+n 2+n 3+n 4+n 5}{5}\right) \times 25 \times 10^{4}
$$

di mana:

$\mathrm{N} \quad=$ jumlah sel hemosit (sel $/ \mathrm{mL})$

$n 1, n 2, n 3, n 4, n 5=$ jumlah sel hemosit dalam kotak kecil hemositometer (sel)

Data sintasan, panjang, bobot, dan total sel hemosit dianalisis dengan menggunakan Anova.

\section{HASIL DAN BAHASAN}

\section{Populasi Bakteri Probiotik Serbuk}

Populasi bakteri probiotik RICA cair sebelum dikemas dalam bentuk serbuk adalah $1 \times 10^{10} \mathrm{cfu} / \mathrm{mL}$ untuk RICA-1; 3,9 x 109 cfu/mL RICA-4; dan 1,69 × $10^{9}$ cfu/mL RICA-5. Setelah ditambahkan tepung kanji dengan perbandingan 1:2 (v:w) dan dikeringkan dalam oven pada suhu $40^{\circ} \mathrm{C}$, maka populasi bakteri probiotik serbuk RICA-1 menjadi 7,23 × $10^{8} \mathrm{cfu} / \mathrm{mL}$ sedangkan untuk RICA-4 dan RICA-5 masing-masing menjadi 1,47 $\times 10^{9} \mathrm{cfu} / \mathrm{mL}$ dan $8,35 \times 10^{8} \mathrm{cfu} / \mathrm{mL}$ (Gambar 2). Probiotik serbuk inilah yang selanjutnya digunakan pada tahap pemeliharaan udang windu. 


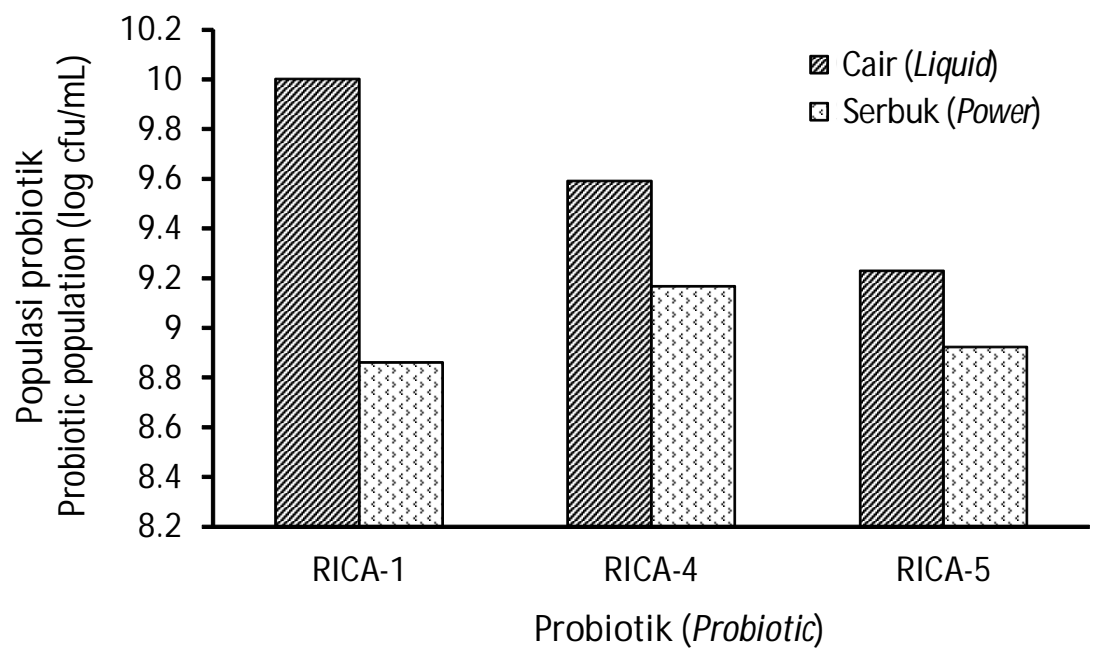

Gambar 2. Populasi probiotik RICA dalam bentuk cair dan setelah dikemas dalam bentuk serbuk.

Figure 2. Population of RICA probiotics in liquid form and after powdering.

Pada umumnya bacillus memiliki endospora (Newman, 2011), adanya sifat ini menyebabkan bacillus sangat mungkin untuk dikemas dalam berbagai bentuk, termasuk diserbukkan. Bentuk kemasan probiotik dapat berupa bentuk cair (liquid), serbuk, pelet, kapsul atau pun tablet. Pada prinsipnya pemilihan bentuk kemasan ini sangat berkaitan dengan upaya untuk mengurangi adanya kontaminasi terhadap produk, serta mempermudah dalam transportasi dan penyimpanan.

Tingginya populasi bakteri probiotik RICA yang ditepungkan dengan cara yang sangat sederhana ini dapat memberi harapan untuk pengembangannya. Pada pembuatan probiotik RICA dengan menggunakan maltosa 20\%(v/w) sebagai filler kemudian diserbukkan dengan memakai freeze drying juga mengalami penurunan sekitar $10 \mathrm{cfu} / \mathrm{mL}$ (Ambarwati, 2015). Penyebab turunnya populasi probiotik pada metode spray drying antara lain adalah karena tipisnya penyalut dari probiotik sehingga tidak dapat melindungi bakteri dari panasnya alat spray drying. Namun penyalut yang terlalu banyak juga dapat menyebabkan populasi bakteri per gram menjadi lebih rendah (Yulinery \& Nurhidayat, 2012).

Performa bakteri probiotik serbuk RICA pada percobaan penyimpanan probiotik serbuk ini di suhu ruang dapat dilihat pada Gambar 3.

Populasi bakteri probiotik serbuk cenderung mengalami penurunan, setelah disimpan selama 10 bulan, probiotik RICA-1 turun satu desimal, RICA-4 dan 5 turun dua hingga tiga desimal, walaupun demikian hasil pengamatan ini masih belum konsisten. Hal ini menunjukkan bahwa bakteri probiotik belum homogen melekat pada tepung kanji yang digunakan sehingga metode sederhana ini perlu diperbaiki lagi supaya probiotik serbuk yang dihasilkan lebih homogen. Nampaknya penelitian ini memberikan hasil yang lebih baik dibanding yang diperoleh Yulinery \& Nurhidayat (2012), hanya mampu menyimpan bakteri yang sudah dienkapsulasi selama dua minggu.

\section{Sintasan Juvenil Udang Windu}

Sintasan udang windu yang dipelihara dengan menggunakan probiotik serbuk RICA dapat dilihat pada Gambar 4. Sintasan tertinggi diperoleh pada udang yang dipelihara dengan menggunakan probiotik RICA4 yakni $81 \pm 12,3 \%$ disusul penggunaan probiotik RICA-1 69,5 $\pm 3,5 \%$ kontrol $69,3 \pm 12 \%$ dan RICA-5 $63 \pm 4,6 \%$

Pemberian probiotik RICA serbuk belum memberikan pengaruh yang signifikan $(P>0,05)$ terhadap sintasan udang windu yang dipelihara (Gambar 4). Gunarto \& Hendrajat (2008) juga melaporkan efek pemberian probiotik pada pemeliharaan juvenil udang vaname tidak signifikan meningkatkan sintasan dan produksi, akan tetapi cenderung memperbaiki kualitas air. Hal yang sama diperoleh Silva et al. (2011) pada pemeliharaan larva hingga post larva udang vaname dengan menggunakan probiotik komersil dan Pham et al. (2014) pada pemeliharaan post larva udang vaname selama sembilan hari dengan pemberian probiotik Pseudoalteromonas. Namun demikian beberapa penelitian penggunaan probiotik pada pemeliharaan 


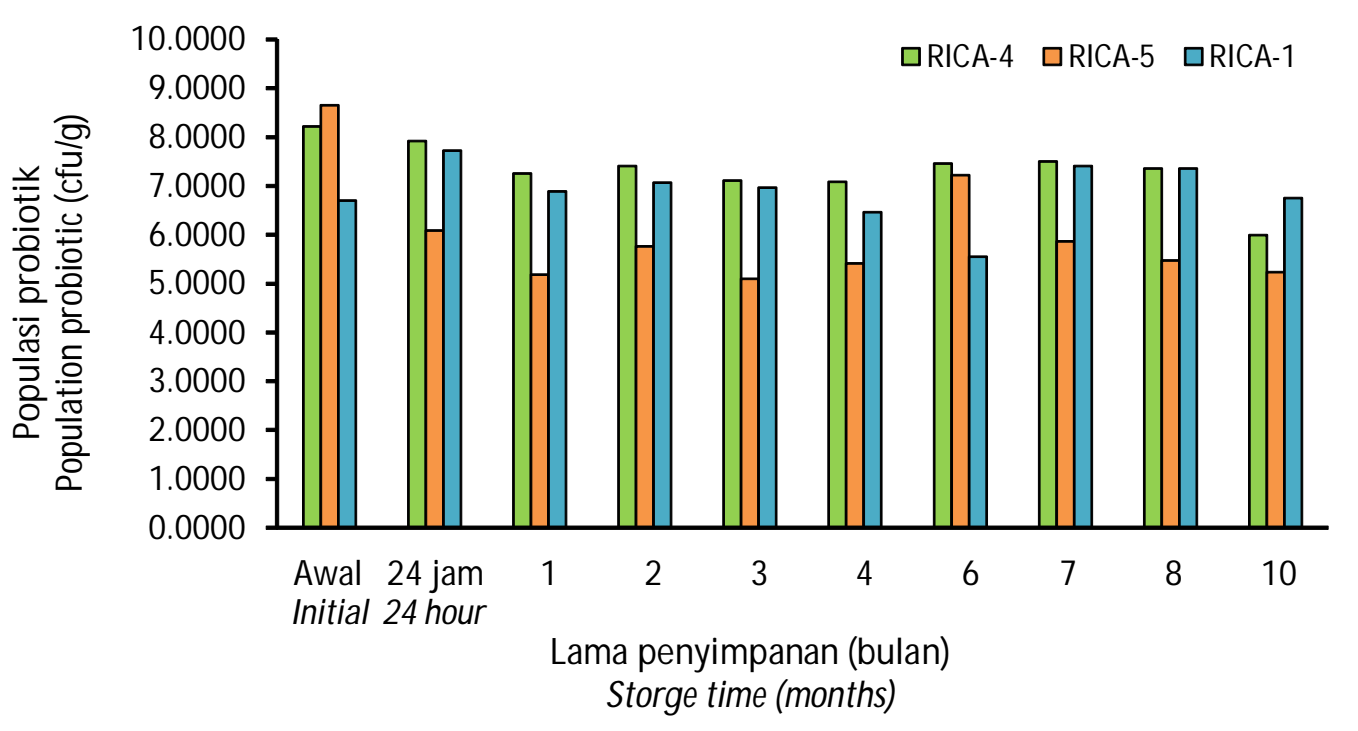

Gambar 3. Populasi probiotik RICA bentuk serbuk setelah disimpan selama sepuluh bulan.

Figure 3. Population of RICA probiotic in powder form after ten months storage.

udang memberikan hasil yang signifikan berbeda dibanding tanpa probiotik, seperti yang dilaporkan oleh Newman (2011) bahwa pemberian probiotik bacillus dapat meningkatkan sintasan dan produksi udang windu.

\section{Bobot dan Panjang Juvenil Udang Windu}

Bobot dan panjang udang pada penelitian ini setelah dipelihara selama $\pm 1,5$ bulan adalah $0,4112 \pm 0,0683$ $\mathrm{g}: 3,9 \pm 0,3 \mathrm{~cm}$ pada kontrol; $0,4107 \pm 0,1603 \mathrm{~g}$ : $3,8 \pm 0,8 \mathrm{~cm}$ pada perlakuan C (RICA-1); 0,3221 \pm
0,1941 g : 3,5 $\pm 0,4 \mathrm{~cm}$ pada perlakuan A (RICA-4); dan 0,3191 $\pm 0,336 \mathrm{~g}: 3,6 \pm 0,3 \mathrm{~cm}$ pada perlakuan B (RICA-5) (Gambar 5).

\section{Total Sel Hemosit}

Sel hemosit dapat menjadi indikasi kondisi fisiologis atau pun tingkat kesehatan udang. Sel hemosit udang terdiri atas sel granular, semi-granular dan hialin (Braak, 2002). Gambaran total sel hemosit udang windu pada penelitian ini dapat dilihat pada Gambar 6.

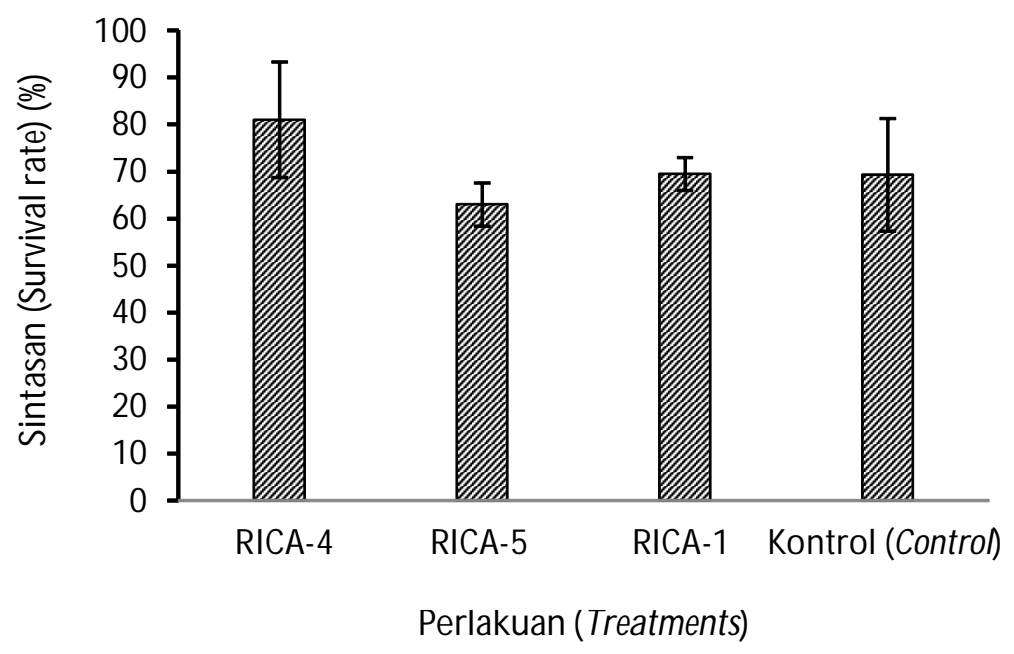

Gambar 4. Sintasan juvenil udang windu P. monodon yang dipelihara dengan menggunakan probiotik RICA serbuk.

Figure 4. Survival rate of shrimp juvenile P. monodon reared with the application of RICA powder probiotics. 

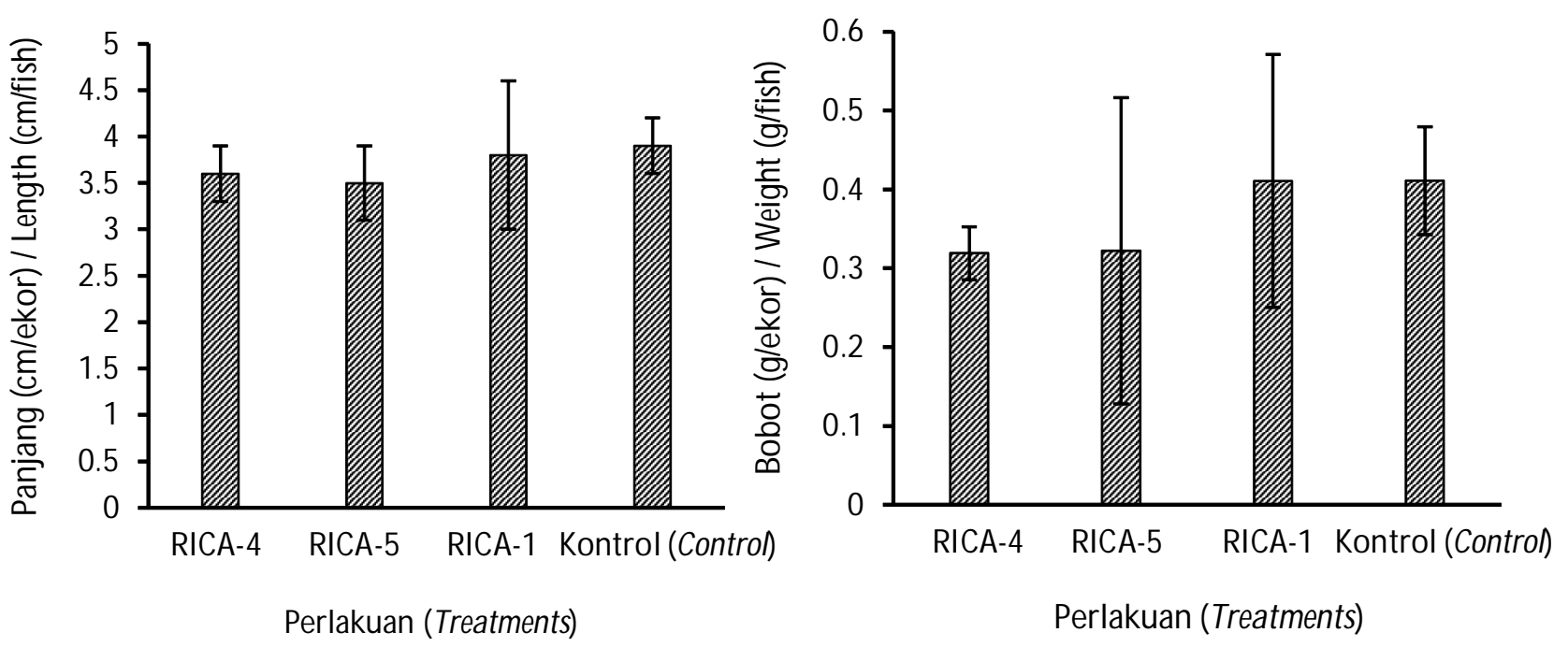

Gambar 5. Panjang (kiri) dan bobot (kanan) juvenil udang windu yang dipelihara dengan menggunakan probiotik RICA serbuk.

Figure 5. Body length (left) and body weight (right) of shrimp juvenile P. monodon reared with the application of RICA powder probiotics.

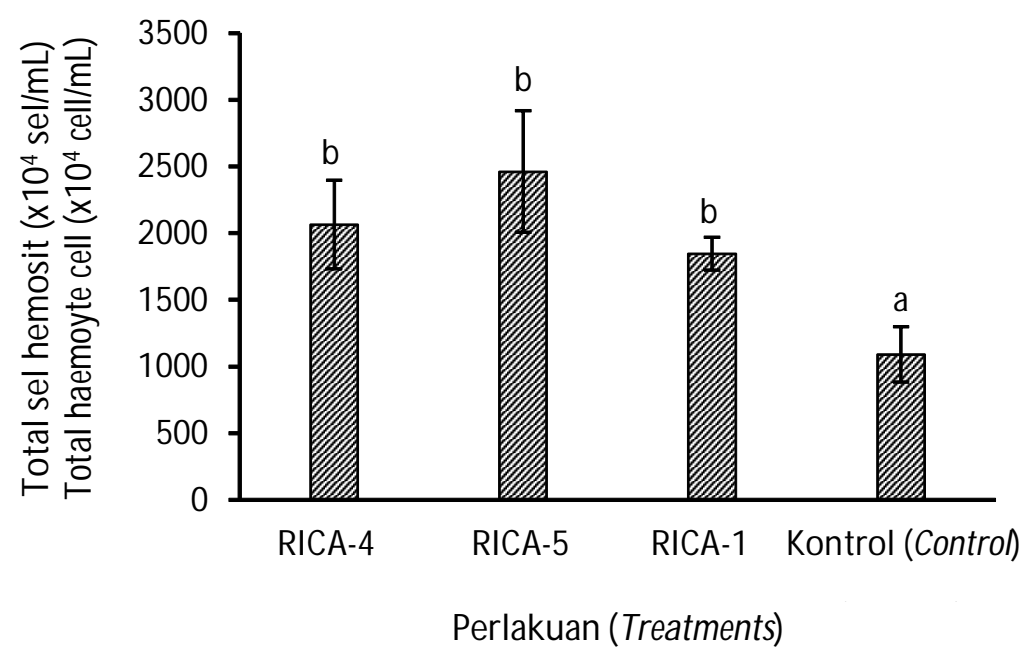

Gambar 6. Total sel hemosit udang windu yang dipelihara dengan menggunakan probiotik RICA serbuk.

Figure 6. Total hemocytes cells of shrimp P. monodon reared with the application of RICA powder probiotics.

Total sel hemosit udang yang dipelihara adalah $2,462 \times 10^{7} \pm 4,56 \times 10^{6} \mathrm{sel} / \mathrm{mL}(\mathrm{B}) ; 2,065 \times 10^{7} \pm$ $3,32 \times 10^{6} \mathrm{sel} / \mathrm{mL}(\mathrm{A}) ; 1,847 \times 10^{7} \pm 1,23 \times 10^{6} \mathrm{sel} / \mathrm{mL}$ (C); dan $1,092 \times 10^{7} \pm 2,08 \times 10^{6} \mathrm{sel} / \mathrm{mL}$ (kontrol) (Gambar 6). Sel hemosit yang tinggi dapat disebabkan oleh adanya peptidoglukan yang terdapat dalam probiotik yang diberikan. Pemberian probiotik secara signifikan dapat meningkatkan total sel hemosit dan ditunjukkan dengan jumlah sel tertinggi diperoleh pada aplikasi probiotik RICA-5 (Gambar 6). Hal ini tidak sejalan dengan data sintasan yang diperoleh (Gambar 5). Penyebab rendahnya sintasan pada perlakuan probiotik RICA-5 dibanding kontrol (walaupun tidak signifikan) pada penelitian ini kemungkinan disebabkan oleh keterlambatan probiotik ini menempel pada udang ataupun karena jumlahnya yang masih sedikit sehingga tidak dapat melawan bakteri patogen yang mungkin sudah terdapat pada tubuh udang yang dipelihara (Bermudezbrito et al., 2012). Hal ini juga sejalan dengan hasil penelitian Silva et al. 
(2011) yang mendapatkan sintasan pasca-larva udang vaname yang lebih rendah setelah sembilan hari masa pemeliharaan. Data total sel hemosit dapat memberikan bukti bahwa probiotik RICA dalam kemasan serbuk dengan metode yang sederhana masih dapat melakukan fungsinya, karena salah satu fungsi probiotik untuk meningkatkan imunitas (Vrieze et al., 2010 dalam Sanchezortiz et al., 2015). Bermudezbrito et al. (2012) menyarankan untuk memperhatikan metode kultur probiotik karena kondisi kultur kemungkinan dapat memengaruhi ekspresi karakter molekuler probiotik. Pemilihan metode yang tidak tepat dapat menyebabkan penurunan fungsi dari probiotik yang dikultur.

Probiotik serbuk RICA-5 dan RICA-4 adalah isolate Bacillus licheniformis dan Bacillus subtilis yang diisolasi dari makroalga/rumput laut (Tampangallo \& Nurhidayah, 2010). Sanchesortiz et al. (2015) melaporkan bahwa pemberian isolat Bacillus subtilis pada pemeliharaan udang vaname dapat meningkatkan total sel hemosit udang secara signifikan. Hasil penelitian Chandran et al. (2014) menunjukkan pemberian probiotik bacillus pada pakan udang windu dapat juga meningkatkan total sel hemosit, aktivitas phenoloksidase, respiratory burst, konsentrasi protein plasma, dan aktivitas antibakteri. Pemberian probiotik juga dapat meningkatkan ekspresi gen Litsty PEN3 (Pham et al., 2014). Hal ini disebabkan adanya peptidoglukan dalam probiotik yang dapat bersinergi positif dengan sistem pertahanan tubuh udang yang dominan yang dilakukan oleh hemosit. Kehadiran bakteri patogen dapat merangsang udang untuk memproduksi hemosit, mengaktifkan fagositosis, prophenoloksidase, antimicrobial peptides (AMPs) seperti penaidins, crustin, dan anti-lipopolysaccharide factors (ALFs) (Tassanakajon et al., 2011). Hal inilah yang menyebabkan mortalitas juvenil udang vaname yang dipelihara dengan menambahkan $B$. subtilis dalam pakan lebih rendah setelah dipapar Vibrio harveyi $10^{5}$ cfu/mL selama 24 jam (Balcazar \& Rojas-Luna, 2007). Probiotik bacillus dapat hidup dalam jumlah yang mencukupi dan menstimulasi enzim dalam saluran pencernaan untuk bekerja lebih baik (Soccol et al., 2010).

\section{KESIMPULAN}

Populasi probiotik RICA kemasan serbuk setelah disimpan selama 10 bulan masih memenuhi standar (minimal $10^{6} \mathrm{cfu} / \mathrm{mL}$ ). Probiotik RICA kemasan serbuk belum signifikan meningkatkan sintasan dan pertumbuhan akan tetapi viabilitasnya masih tetap aktif, yang ditandai dengan signifikannya total sel hemosit.

\section{UCAPAN TERIMA KASIH}

Penelitian ini terlaksana atas dukungan tim peneliti dan teknisi Kesehatan Ikan dan Lingkungan, serta tim Instalasi Perbenihan Udang Windu Balai Riset Perikanan Budidaya Air Payau dan Penyuluh Perikanan di Kabupaten Barru.

\section{DAFTAR ACUAN}

Ambarwati, D. (2015). Populasi probiotik RICA-1 powder dengan penambahan maltosa $20 \%$ Komunikasi pribadi.

Atmomarsono, M., Muliani, \& Nurbaya. (2009). Penggunaan bakteri probiotik dengan komposisi berbeda untuk perbaikan kualitas air dan sintasan pascalarva udang windu. J. Ris. Akuakultur, 4(1), 7383.

Balcazar, J.L., \& Rojas-Luna, T. (2007). Inhibitory activity of probiotic Bacillus subtilis UTM 126 against vibrio species confers protection against vibriosis in juvenile shrimp (Litopenaeus vannamei). Curr. Microbiol., 55, 409-412. DOI: 10.1007/s00284-0079000-0.

Bermudezbrito, M., Plaza-Diaz, J., Munoz-Quezada, S., Gomez-Llorente, C., \& Gil, A. (2012). Probiotic mechanisms of action. Ann. Nutr. Metab., 61, 160174. DOI: $10.1159 / 000342079$.

Braak, V.D.K. (2002). Haemocytic defence in black tiger shrimp (Penaeus monodon). Thesis. Wageningen University. Netherlands, $168 \mathrm{pp}$.

Chandran, M.N., Iyapparaj, P., Moovendhan, S., Ramasubburayan, R., Prakash, S., Immanuel, G., \& Palavesam, A. 2014. Influence of probiotic bacterium Bacillus cereus isolated from the gut of wild shrimp Penaeus monodon in turn as a potent growth promoter and immune enhancer in $P$. monodon. Fish \& Shellfish Immunology (36):38-45.

Gunarto, \& Hendrajat, E.A. (2008). Budidaya udang vaname, Litopenaeus vannamei pola semiintensif dengan beberapa jenis probiotik komersil. J. Ris. Akuakultur, 3(3), 339-349.

Haseeb, M. (2011). Development of zero water exchange shrimp culture system integrated with bioremediation of detritus and ammonia-nitrogen. Thesis. Cochin University of Science and Technology, 293 pp.

Muliani, Nurbaya, \& Atmomarsono, M. (2006). Penapisan bakteri yang diisolasi dari tambak udang sebagai kandidat probiotik pada budidaya udang windu, Penaeus monodon. J. Ris. Akuakultur, $1(1), 73-85$.

Muliani, Nurbaya, \& Susianingsih, E. (2011). Karakterisasi dan identifikasi molekuler isolat BT951 serta evaluasi potensinya sebagai bakteri 
probiotik pada budidaya udang windu (Penaeus monodon). J. Ris. Akuakultur, 6(3), 457-468.

Newman, S.G. (2011). Pro 4000X. Advanced biotechnology for pond water quality (Environment) management. www.bioremediationaquaculture.com atau www.aqua-in-tech.com.

Pham, D., Ansquer, D., Chevalier, A., Dauga, C., Peyramale, A., Wabete, N., \& Labreuche, Y. (2014). Selection and characterization of potential probiotic bacteria for Litopenaeus stylirostris shrimp hatcheries in New Caledonia. J. Aquaculture. DOI: 10.1016/j.aquaculture.2014.04.031.

Soccol, C.R., Vandenberghe, L.P., Spier, M.R., Medeiros, A.B.P., Yamaguishi, Lindner, J.D., Pandey, A., \& Thomaz-Soccol, V. (2010). The potential of probiotic, Food Technol. Biotechnol., 48(4), 413-434.

Tahe, S., Suwoyo, H.S., \& Fahrur, M. (2015). Aplikasi probiotik RICA dan komersial pada budidaya udang vaname (Litopenaeus vannamei) pola intensif. Prosiding Forum Inovasi Teknologi Akuakultur, hlm. 435-445.

Tampangallo, B.R., \& Nurhidayah. (2010). Pemantauan populasi bakteri pada beberapa jenis rumput laut. Prosiding Seminar Perikanan Nasional. Universitas Hang Tuah. Surabaya, hlm. 4.

Tassanakajon, A., Amparyup, P., Somboonwiwat, K., $\&$ Supungul, P. (2011). Cationic antimicrobiol peptides in penaeid shrimp. Marine Biotechnology Journal, 13, 639-657.

Sanchezortiz, A.C., Luna-Gonzales, A., Campa-Cordova, A.I., Escamilla-Montes, R., Flores-Miranda, M.C., \& Mazon-Suastegui, J.M. (2015). Isolation and characterization of potential probiotic bacteria from pustulose ark (Anadara tuberculosa) suitable for shrimp farming. Lat. Am. J. Aquat. Res., 43(1), 123-136.

Silva, E.F., Soares, M.A., Calazans, N.F., Vogeley, J.L., Valle, B.C., Soares, R., \& Peixoto, S. (2011). Effect of probiotik (Bacillus spp.) addition during larvae and postlarvae culture of the white shrimp Litopenaeus vannamei. Aquaculture Research, p. 1-9. DOI: 10.1111/j.1365-2109.2011.03001x.

Sulestiani, A., Pasaribu, A.M., Subianto, A., \& Huda, M.Kh. (2016). Pemanfaatan probiotik di tambak udang windu (Penaeus monodon, F.) untuk mengatasi penyakit udang "White Spot Syndrome Virus" (WSSV) di Desa Srowo Kecamatan Sidayu Kabupaten Gresik, Jawa Timur. Majalah Aplikasi Ipteks NGAYAH, 7(1), 100-109.

Widanarni, Noermala, J.I., \& Sukenda. (2014). Prebiotik, probiotik, dan sinbiotik untuk mengendalikan koinfeksi Vibrio harveyi dan IMNV pada udang vaname. J. Akuakultur Indonesia, 13(1), 11-20.

Yulinery, T., \& Nurhidayat, N. (2012). Analisis viabilitas probiotik Lactobacillus terenkapsulasi dalam penyal ut dekstrin dan jus markisa (Passiflora edulis). J. Tek. Ling., 13(1), 109-121.

Zokaei, H.F., Saad, C.R.B., Daud, H.M., Sharr Azni Harmin, S.A., \& Shakibazadeh, S. (2009). Effect of Bacillus subtilis on the growth and survival rate of shrimp (Litopenaeus vannamei). African Journal of Biotecnoogy, 8(14), 3369-3376. 